\title{
Distribution of $\mathrm{ABO}$ blood groups and $\mathrm{Rh}(\mathrm{D})$ factor in and around Anatapuramu, Andhra Pradesh
}

\author{
C. Bhavani ${ }^{1}$, R. Sujeeva Swapna ${ }^{2}$, M. Neeraja ${ }^{3}$, P.Sravani $^{4}$, B.Chaitanya ${ }^{5}$ \\ ${ }^{1}$ C. Bhavani, ${ }^{2}$ R.Sujeeva Swapna, ${ }^{3}$ M. Neeraja, ${ }^{4}$ P.Sravani, ${ }^{5}$ B. Chaitanya. All are affiliated with Dr. NTR University of \\ Health sciences, Vijayawada, Andhra Pradesh, India.
}

Address for Correspondence: Dr. C.Bhavani, 12-3-435, Balaji Apartments, Besides MORE supermarket, Jesus Nagar, Anantapur, Andhra Pradesh, India. E-mail: dr.cbhavani@gmail.com

\begin{abstract}
Background: India is a vast country with lot of diversity in race, religion and creed. The same diversity has been observed in geographical distribution of blood groups in population within country. ABO and Rh blood groups are most important blood groups in human beings. Objectives: A retrospective study was conducted at Government Medical College/ Government General Hospital Blood Bank Anantapuramu over a period of one year from January 2014 to December 2014 to determine and compare the distribution of ABO and Rh blood groups. Materials and Methods: A retrospective study of one year was carried out at our blood bank in Government Medical College \& Hospital, Anantapuramu in Andhra Pradesh, South India. Data pertaining to the blood groups of donors was collected from the Blood Bank donor register from January 2014 to December 2014. Results: The total donors studied from January 2014 to December 2014 were 6942. The distribution of blood groups was : blood group 'A' 1386 ( $20 \%$ ), 'B' 2489 ( 35.8 \% ), 'AB' 509 ( $7.3 \%$ ) and ' $\mathrm{O}$ ‘ 2558 ( $36.9 \%$ ). In both Rh D positive and Rh D negative person's blood group ' $\mathrm{O}$ “ was the commonest followed by blood group " $\mathrm{B}$ " Blood group “ $\mathrm{AB}$ " is the least common. Conclusion: The "O" blood group is significantly high in our population and comparatively low "AB" blood group. Every transfusion center should have a record of frequency of blood group system in their population. The study of distribution of blood group is very important for blood banks and transfusion services that could contribute to the patients' health care.
\end{abstract}

Key words: ABO blood group, Rh (D) factor, Blood Bank

\section{Introduction}

Up till now about 400 erythrocyte antigens have been identified. International Society of Blood Transfusion organized them into 30 blood group systems of which $\mathrm{ABO}$ and $\mathrm{Rh}$ systems are important for transfusion purpose [1].

The discovery of $\mathrm{A}, \mathrm{B}$ and $\mathrm{O}$ blood groups by Karl Landsteiner in 1900 was an important achievement in the history of blood transfusion. Alfred Von Decastello and Adriano Sturli discovered the fourth type AB, in 1902. Later Rh group was discovered by Landsteiner and Weiner in 1941 [2]. Blood groups are genetically determined. The vast majority are inherited by Mendelian fashion. The genes of ABO and Rh ( D ) are

Manuscript received: $06^{\text {th }} \mathrm{Feb} 2016$

Reviewed: $15^{\text {th }}$ Feb 2016

Author Corrected: $24^{\text {th }}$ Feb 2016

Accepted for Publication: $03^{\text {rd }}$ March 2016 located on chromosome 9 and 1 respectively [3]. The incidence of $\mathrm{ABO}$ and $\mathrm{Rh}$ groups varies markedly in different races, ethnic groups, across geographical boundaries and also from time to time in the same region [4]. The knowledge on $\mathrm{ABO}$ and $\mathrm{Rh}$ blood group systems is not only highly essential for effective management in the blood bank inventory but also useful in population genetic studies, researching population migration patterns and for forensic purposes [1].

Blood groups are also known to have some association with diseases like duodenal ulcer, diabetes mellitus, urinary tract infection, $\mathrm{Rh}$ incompatibility, cardiovascular diseases and malignancies [5]. This study is aimed to determine frequency and distribution of $\mathrm{ABO}$ and $\mathrm{Rh}$ blood group patterns among voluntary blood donors in a tertiary care teaching hospital in 
South India and compare with other data from similar studies within India and all over the world.

\section{Materials and Methods}

A retrospective study of one year was carried out at our blood bank in Government Medical College \& Hospital, Anantapuramu in Andhra Pradesh, South India. Data pertaining to the blood groups of donors was collected from the transfusion centre from January 2014 to December 2014. A total of 7055 people volunteered for donation during this period of which 113 were rejected due to detection of HIV, HBV and HCV. 6942 cases were considered medically fit for donation. The donors were in the age group between $20-55$ years.

Blood samples were collected by standard procedure of venepuncture. Both forward and reverse grouping were carried out for confirmation of blood group. Commercially available antisera anti A, anti B and anti $\mathrm{D}$ were used for agglutination reactions after validation. Reverse grouping was performed using daily prepared pooled A, B and O cells. Data was recorded on a specially prepared proforma and analyzed.

\section{Observations and Results}

The total donors studied from January 2014 to December 2014 were 6942. Out of these 6942 subjects, 6922 (99.7\%) were male donors and $20(0.3 \%)$ were female. The frequency of $\mathrm{ABO}$ and $\mathrm{Rh}$ blood groups in the studied population is shown in Table 1.

Table 1: Frequency Distribution of ABO and Rh blood groups in the current study

\begin{tabular}{|l|l|l|l|l|l|l|}
\hline $\begin{array}{l}\text { ABO } \\
\text { group }\end{array}$ & $\begin{array}{l}\text { Rhood } \\
\text { Positive }\end{array}$ & $\begin{array}{l}\text { Percentage } \\
(\mathbf{\%})\end{array}$ & Rh Negative & $\begin{array}{l}\text { Percentage } \\
(\mathbf{\%})\end{array}$ & Total & $\begin{array}{l}\text { Percentage } \\
(\mathbf{\%})\end{array}$ \\
\hline A & 1325 & 19.08 & 61 & 0.87 & 1386 & 19.96 \\
\hline B & 2399 & 34.55 & 90 & 1.29 & 2489 & 35.85 \\
\hline AB & 499 & 7.18 & 10 & 0.14 & 509 & 7.33 \\
\hline O & 2461 & 35.4 & 97 & 1.39 & 2558 & 36.85 \\
\hline Total & $\mathbf{6 6 8 4}$ & $\mathbf{9 6 . 2 8}$ & $\mathbf{2 5 8}$ & $\mathbf{3 . 7 2}$ & $\mathbf{6 9 4 2}$ & $\mathbf{1 0 0}$ \\
\hline
\end{tabular}

Table 2: Comparative study on frequency of $\mathrm{ABO}$ and Rh phenotypes at different geographical areas

\begin{tabular}{|c|c|c|c|c|c|c|}
\hline Within India & $\mathbf{A}$ & B & $\mathbf{A B}$ & $\mathbf{O}$ & Rh Positive & Rh Negative \\
\hline Current Study in South India & $20 \%$ & $35.8 \%$ & $7.3 \%$ & $36.9 \%$ & $96.28 \%$ & $3.72 \%$ \\
\hline Bangalore & $23.85 \%$ & $29.95 \%$ & $6.37 \%$ & $39.82 \%$ & $94.2 \%$ & $5.8 \%$ \\
\hline Chittoor & $18.95 \%$ & $25.79 \%$ & $7.89 \%$ & $47.37 \%$ & $90.6 \%$ & $8.42 \%$ \\
\hline Vellore & $21.86 \%$ & $32.69 \%$ & $6.7 \%$ & $38.75 \%$ & $94.5 \%$ & $5.5 \%$ \\
\hline North India & $21.7 \%$ & $39.8 \%$ & $9.33 \%$ & $29.1 \%$ & $95.71 \%$ & $4.29 \%$ \\
\hline West India & $21.94 \%$ & $39.4 \%$ & $7.86 \%$ & $30.79 \%$ & $95.05 \%$ & $4.95 \%$ \\
\hline Central India & $24.15 \%$ & $35.25 \%$ & $9.10 \%$ & $31.5 \%$ & $95.43 \%$ & $4.57 \%$ \\
\hline East India & $23.9 \%$ & $33.6 \%$ & $7.7 \%$ & $34.8 \%$ & $94.7 \%$ & $5.3 \%$ \\
\hline \multicolumn{7}{|l|}{ OUTSIDE INDIA } \\
\hline USA & $41 \%$ & $9 \%$ & $4 \%$ & $46 \%$ & $85 \%$ & $15 \%$ \\
\hline Britain & $41.7 \%$ & $8.6 \%$ & $3 \%$ & $46.7 \%$ & $83 \%$ & $17 \%$ \\
\hline Australia & $38 \%$ & $10 \%$ & $3 \%$ & $49 \%$ & NA & NA \\
\hline Pakistan & $22.4 \%$ & $32.4 \%$ & $8.4 \%$ & $30.5 \%$ & $93 \%$ & $7 \%$ \\
\hline Nepal & $34 \%$ & $29 \%$ & $4 \%$ & $33 \%$ & $96.7 \%$ & $3.33 \%$ \\
\hline
\end{tabular}

NA: Not Available

The distribution of blood groups was : blood group 'A' 1386 ( $20 \%$ ), ‘ B ‘ 2489 ( $35.8 \%$ ), 'AB' 509 ( $7.3 \%$ ) and ' O ' 2558 ( $36.9 \%$ ). In both Rh D positive and Rh D negative person's blood group ' $\mathrm{O}$ ' was the commonest followed by 
blood group ' $\mathrm{B}$ '. Blood group 'AB ' is the least common. We compared our data with various studies conducted both inside and outside India as can be seen in Table 2.

\section{Discussion}

India carries a lot of diversity in the distribution of blood groups. Knowledge of frequency of blood groups is essential in determining the direction of recruitment of voluntary donors as required for different zones of the country.

In India, because of varied cultural habits, social taboos, lack of motivation and fear of blood donation, female donors are very less. In addition large number of females from the menstruating age group is anaemic with low weight, so declared unfit for blood donation [6]. In our study we observed a significantly low percentage of female donors (0. $3 \%$ ). Akin to the studies of Mallikarjuna $\mathrm{S}$ and Giri PA et al it is observed that the predominant percentage of blood donors is males. $[1,7,8]$

In the present study, the ABO blood group typing in the total sample showed the same trend of prevalence as other studies conducted in South India (Bangalore, Chittoor and Vellore) $\{\mathrm{O}>\mathrm{B}>\mathrm{A}>\mathrm{AB}\}[9,10,11]$. Geographic distribution of blood groups in India shows that in Northern, Central and Western parts of India ' B' is the commonest blood group whereas in Eastern and Southern India ' $\mathrm{O}$ ' is the most frequently occurring blood group [6].

Internationally studies pertaining to USA [12], Britain [13], Australia [14] and Pakistan [15] showed ' $O$ ' blood group to be the most prevalent. Only in Nepal which is connected to Western India 'A 'blood group was found with a slightly higher frequency than ' $\mathrm{O}$ ' blood group[16].

Pertaining to Rhesus system, in our study frequency of Rh positive was $96.28 \%$, while only $3.72 \%$ was $\mathrm{Rh}$ negative. These figures are similar to the figures from other studies carried out in different parts of India. Rh positive groups are the predominant groups. In comparison similar frequencies of prevalence of $\mathrm{Rh}$ groups were found in Nepal whereas studies across USA and Britain showed a higher fraction of prevalence of Rh negative groups.[12,13,16].

\section{Conclusion}

Knowledge of blood groups is highly essential for transfusion services which contribute to patient's health care. Access to safe and sufficient blood supply will help to reduce the morbidity and mortality rates. Our study has a significant implication of generation of a simple database of blood groups in this area. It not only provides scientific data but also serves to enable insight into possibilities of future burden of blood group associated diseases.

\section{Funding: Nil \\ Conflict of interest: None. Permission of IRB: Yes}

\section{References}

1. A Patel Piyush, P Patel Sangeetha, V Shah Jigesh, V Oza Haren. Frequency and Distribution of Blood Groups in Blood Donors in Western Ahmedabad - A Hospital Based Study. Natl J Med Res. (2012); 2(2): 202-206.

2. SK.Mishra, Naresh Bajaj, Prabhakar Singh, Keshav Singh, Pallavi Indurkar. Frequency \& distribution of $\mathrm{ABO}$ and $\mathrm{RH}$ (Factor) blood groups among medical students of Central India, Rewa, Madhya Pradesh. IJPCBS. 2014; 4(4) : 980-984.

3. Himanshu shekhar, Ashmeet kaur, Pooja Jadeja, Parihar, P. M. \& Ketan K Mangukiya. Frequency and distribution of $\mathrm{ABO}$ blood group and $\mathrm{RH}$ (D) factor in Southern Rajasthan. I.J.S.N. 2014; 5 (3) : 494-497.

4. Gadwalkar Srikant R, Sunil Kumar N, Ravidhar. Distribution of Blood Groups in and around Bellary, Karnataka. Indian Journal of Clinical Practice.2013; 24 (3) : $247-250$.

5. Enosolease ME, Bazuaye GN. Distribution of ABO and Rh-D blood groups in the Benin area of NigerDelta: Implication for regional blood transfusion. Asian J Transfus Sci. 2008 Jan;2(1):3-5. doi: 10.4103/09736247.39502 .

6. Garg P, Upadhyay S, Chufal SS, Hasan Y, Tayal I. Prevalance of ABO and Rhesus Blood Groups in Blood Donors: A Study from a Tertiary Care Teaching Hospital of Kumaon Region of Uttarakhand. J Clin Diagn Res. 2014 Dec;8(12):FC16-9. doi: 10.7860/JCDR/2014/9794.5355. Epub 2014 Dec 5. 
7. Mallikarjuna S. Prevalence of $\mathrm{ABO}$ and Rhesus blood group among blood donors. Indian Journal of Public Health, Research and Development. 2011.

8. Giri P A, Yadav S, Parhar G S, Phalke D B. Frequency of ABO and Rhesus Blood Groups: A Study from a Rural Tertiary Care Teaching Hospital in India. Int J Biol Med Res. 2011; 2 (4): 988-990.

9. Periyavan S, Sangeetha SK, Marimuthu P, Manjunath BK, Seema DM. Distribution of ABO and Rhesus-D blood groups in and around Bangalore. Asian J Transfus Sci. 2010 Jan;4(1):41. doi: 10.4103/0973-6247.59391.

10. Reddy K S N, Sudha G and Rh (D) blood groups among the Desuri Reddis of Chittoor District, Andhra Pradesh. Anthropologist. 2009; 11 (3): 237-238.

11. groups among blood donors in a tertiary care centre in South India. Trop Doct. 2001 Jan;31(1):47-8.
12. Mollison P L, Engelfriet C P, Conteras M. The Rh blood Group system. In Blood Transfusion in Clinical Medicine, $9^{\text {th }}$ Edition. Oxford: Black well Scientific Publication.1993; 2008-9.

13. Frances TF: Blood groups (ABO groups). In: Common Laboratory and Diagnostic Tests. Philadelphia: Lippincott. 2002, 3rd Edition: 19-5.

14. Australian Red Cross society. All about blood. URL: www.donateblood.com.au/all-aboutblood/bloodtypes.

15. Hammed A, Hussain W, Ahmed J, Rabbi F, Quersh J A. Prevalence of Phenotypres and Genes of ABO and Rhesus (Rh) blood groups in Faisalabad, Pakistan. Pak J Biol Sci. 2002,; 5(6):722- 724.

16. Pramanik T, Pramanik S. Distribution of ABO and Rh blood groups in Nepalese medical students: a report. East Mediterr Health J. 2000 Jan;6(1):156-8.

\section{How to cite this article?}

C. Bhavani, R. Sujeeva Swapna, M. Neeraja, P.Sravani, B.Chaitanya. Distribution of ABO blood groups and Rh(D) factor in and around Anatapuramu, Andhra Pradesh. Int $J$ Med Res Rev 2016;4(3):372-375. doi: 10.17511/ijmrr.2016.i03.15 